AT-TAJDID: Jurnal Pendidikan Dan Pemikiran Islam

(p-ISSN: 2548-5784 le-ISSN: 2549-2101)

Vol.(4)(01), (Januari-Juni) (2020), (Halaman)(85-101)

Doi: http://dx.doi.org/10.24127/att.v4i01.1227

\title{
EFEKTIFITAS PENGGUNAAN METODE DEMONSTRASI UNTUK MENINGKATKAN HASIL BELAJAR SISWA PADA PEMBELAJARAN IBADAH SHALAT DI KELAS VII A MTSN 1 LAMPUNG TIMUR
}

\author{
FATMAH \\ MTS N I Lampung Timur \\ Umifatmah97@gmail.com
}

\begin{abstract}
Abstrak
Tujuan dari penelitian ini adalah untuk mengetahui bagaimanakah efektifitas dari penggunaan metode demonstrasi dapat meningkatkan hasil belajar siswa pada pembelajaran ibadah shalat di kelas VII A MTSN I lampung timur tahun pelajaran 2020/2021. Metode yang digunakan dalam penelitian ini adalah tindakan kelas (PTK). Penelitian tindakan kelas ini dilaksanakan secara kolaboratif antara peneliti dengan guru mata pelajaran pendidikan agama Islam dengan menggunakan model siklus yang dikembangkan oleh Suharsimi Arikunto terdiri dari, yakni (1) perencanaan, (2) pelaksanaan, (3) pengamatan, (4) refleksi. Siklus yang dilaksanakan dalam penelitian ini terdapat 2 (dua) siklus, yang mana masing-masing siklus mempunyai 3 (tiga) kali pertemuan.

Berdasarkan hasil data penelitian yang berhasil dikumpulkan, dapat disimpulkan bahwa penggunaan metode demonstrasi dapat meningkatkan aktivitas hasil belajar siswa dalam melaksanakan ibadah shalat dengan gerakan dan bacaan yang tepat dalam shalat. Hal tersebut dapat dilihat dari persentase siswa yang tuntas belajar pada siklus I sebesar $52 \%$ dan siklus II sebesar $80 \%$.
\end{abstract}

Kata kunci: Metode Demonstrasi, Pembelajaran Ibadah Shalat.

\begin{abstract}
The purpose of this study is to find out how the use of demonstration methods can improve student learning outcomes in prayer learning in class VII A MTSN I East Lampung in the academic year 2020/2021. The method used in this study is classroom action. This class action research was carried out in collaboration between researchers and teachers of Islamic religious education subjects using the cycle model, namely (1) planning, (2) implementation, (3) observation, (4) reflection. The cycle carried out in this study there are 2 (two) cycles, each of which consists of 3 (three) meetings.

Based on the results of the research data collected, researchers can conclude that the use of demonstration methods can increase student learning outcomes in carrying out prayer services with the right movements and readings in prayer. This can be seen
\end{abstract}


from the percentage of students who finished learning in cycle I by $52 \%$ and cycle II by $80 \%$.

Keywords: Demonstration Method, Learning Shalat.

\section{A. PENDAHULUAN}

Shalat sangat penting dalam Islam karena shalat merupakan hubungan antara seorang hamba dengan sang Penciptanya, disamping itu shalat adalah suatu kewajiban yang diperintahkan kepada ummat Islam bahkan begitu dipentingkan oleh alQur'an mengenai kewajiban untuk melaksanakan shalat, al-Qur'an telah menyatakan kefardhuannya shalat dengan berbagai susunan kata-kata, kadang-kadang dengan perintah tegas dan terkadang dengan memuji-muji orang yang mengerjakan shalat, sehingga dapat dipahami shalat itu adalah suatu kewajiban yang tidak bisa ditinggalkan (Ferista, 2011)..

Shalat lebih tinggi nilainya dari ibadah yang lain karena shalat mendidik manusia untuk berbuat baik dan menjauhkan diri dari segala perbuatan yang dibenci oleh Allah

Artinya:Dirikanlah shalat sesungguhnya shalat itu mencegah dari perbuatan keji dan mungkar dan sesungguhnya mengingat Allah (shalat) adalah lebih besar keuntungannya dari ibadah yang lain dan Allah maha mengetahui apa yang kamu kerjakan.(QS. AlAnkabut : 45) (Departemen Agama, 2005).

Rasulullah SAW juga bersabda :
Artinya :Perintahlah oleh kamu anak-anak untuk mengerjakan shalat setelah berusia 7 tahun dan apabila telah berusia 10 tahun belum juga mengerjakan shalat, maka pukulah dia (HR. Abu Daud).

Faktor-faktor yang mempengaruhi belajar anak yaitu faktor internal dan faktor eksternal. Faktor internal dalam diri anak atau dari lingkungan keluarga. Anak masih meniru atau mencontoh perbuatan dari orang tuanya, orang tua di rumah tidak mengerjakan ibadah shalat, sehingga anak malas untuk melaksanakannya (Nashar, 2004). Orang tuanyalah yang wajib mengajarkan ibadah shalat di rumah karena waktu anak banyak di rumah dari pada di sekolah. Sedangkan faktor eksternal adalah faktor yang dipengaruhi dari sekolah sebagaimana diajarkan ibadah shalat oleh guru dan gurulah yang wajib memberikan pelajaran ibadah shalat dengan baik dan benar sesuai dengan syariat Islam (Slamet, 2003). Adapun yang mempengaruhi pelaksanaan ibadah shalat adalah cara penggunaan metode yang dipakai oleh guru dalam memberikan materi pelajaran masih kurang maksimal sehingga aktivitas dan hasil belajar siswa masih kurang dari KKM. 
Secara faktual pengamalan pendidikan agama Islam membutuhkan tenaga pendidik yang professional dalam rangka mewujudkan tujuan pendidikan agama Islam. Guru adalah salah satu komponen dalam belajar yang ikut berperan di bidang pendidikan. Oleh karena itu guru merupakan salah satu unsur di bidang kependidikan harus berperan secara aktif dalam menempatkan kedudukannya sebagai tenaga profesional sesuai dengan tuntutan masyarakat yang semakin berkembang (Hamalik, 2004).

Tanggung jawab seorang guru pendidikan agama Islam tidak terbatas pada usaha mencerdaskan siswanya saja akan tetapi lebih jauh dari itu bahwa ia mempunyai tanggung jawab secara ukhrowi sesuai kenyataan bahwa pendidikan agama Islam yang diajarkan di sekolah bukan hanya mempelajari ilmu pengetahuan akan tetapi lebih luas lagi yaitu mencakup 3 aspek, yaitu: aspek iman, ilmu dan amal (Arief, 2002). Dengan demikian tugas dan tanggung jawab guru agama Islam adalah adalah mempersiapkan siswa-siswanya ke arah yang lebih baik yaitu jalan yang diridhoi Allah SWT dan menjadi warga negara yang baik.

Salah satu kriteria beriman adalah masalah ibadah shalat karena shalat merupakan ibadah pokok dan kewajiban setiap individu umat Islam, yang perlu dipelajari dan dipraktikkan pada usia anak-anak sejak ini. Dalam mengajarkan bahan pendidikan agama guru harus memilih metode mengajar yang tepat. Dalam hal ini penggunaan metode demonstrasi mempunyai kelebihan, adapun kelebihan menggunakan metode demonstrasi adalah sebagai berikut :

1) Dapat membuatpengajaran menjadi lebih jelas dan lebih konkret sehingga menghindari verbalisme (pemahaman secara kata-kata atau kalimat).

2) Siswa lebih mudah memahami apa yang dipelajari.

3) Proses pengajaran lebih menarik.

4) Siswa dirangsang untuk aktifmengamati, menyesuaikan antara teori dengan kenyataan, dan mencoba melakukannya sendiri (Daradjat, 2016).

Berdasarkan hasil pra survei yang penulis lakukan dengan cara observasi di MTs Negeri 1 Lampung timur, dalam penentuan metode yang tepat dan sesuai dengan pengajaran ibadah khususnya ibadah shalat banyak guru dalam menyampaikan materi menggunakan metode konvensional (ceramah), karena ibadah shalat merupakan rangkaian yang mencakup suatu bentuk perbuatan dan keyakinan sehingga kurang tepat jika dalam penyampaian materi hanya menggunakan metode ceramah dan tanya jawab. Sedangkan aktivitas siswa hanya mendengarkan dan menjawab pertanyaan yang diberikan oleh guru.

Berdasarkan hasil belajar dari hasil tes secara tertulis dan lisan masih 
banyak siswa yang ibadah shalatnya kurang baik bahkan kurang memuaskan sesuai dengan kriteria ketuntasan minimum (KKM) di mana KKM mata pelajaran pendidikan agama Islam adalah 75 yang telah ditentukan oleh sekolah. Adapun prosentase hasil dari pengamatan penulis maka dapat dilihat dari tabel di bawah ini:

Tabel 1

Data Aktivitas yang Diteliti

\begin{tabular}{|l|l|c|}
\hline No & \multicolumn{1}{|c|}{ Aktivitas yang diteliti } & $\begin{array}{c}\text { Prosenta } \\
\text { se (\%) }\end{array}$ \\
\hline 1. & $\begin{array}{l}\text { Memperhatikan guru } \\
\text { dalam menjelaskan materi } \\
\text { pembelajaran. }\end{array}$ & 16 \\
\hline 2. & $\begin{array}{l}\text { Guru memberikan } \\
\text { kesempatan kepada siswa } \\
\text { untuk mempraktikkan } \\
\text { ibadah shalat. }\end{array}$ & 26 \\
\hline 3. & $\begin{array}{l}\text { Gerakan dan bacaan siswa } \\
\text { dalam ibadah shalat }\end{array}$ & 36 \\
\hline 4. & $\begin{array}{l}\text { Siswa mengerjakan latihan } \\
\text { dan berusaha untuk } \\
\text { membaca buku untuk } \\
\text { mengerjakan latihan } \\
\text { tersebut. Jumlah }\end{array}$ & $\mathbf{1 0 0}$ \\
\hline & \multicolumn{1}{|c|}{ Jumbah } \\
\hline
\end{tabular}

Dari tabel di atas, prosentase hasil belajar siswa dalam praktik ibadah shalat terdapat 16 anak (64\%) yang nilai pendidikan agama Islam belum tuntas dan 9 anak (36\%) yang tuntas dalam melaksanakan ibadah ibadah shalat dengan baik dan benar. Dalam hal ini guru belum berhasil dalam mengajarkan ibadah shalat bagi siswasiswanya.
Melihat

permasalahanpermasalahan di atas, maka metode pembelajaran yang dipandang relevan dengan masalah di atas, bahwa penggunaan metode dan sistem pembelajaran yang digunakan guru dapat mempengaruhi aktifitas siswa dalam menetapkan dan melaksanakan ibadah shalat dengan baik dan benar. Dengan penggunaan metode demontrasi diharapkan siswa mampu menghafalkan seluruh bacaan shalat dengan fasih dan ketepatan gerakan shalat sesuai dengan ketentuan dalam agama Islam.

\section{B. METODELOGI}

Dalam penelitian ini peneliti menggunakan jenis data penelitian yang bersifat tindakan kelas (Classroom Action Research) (Arikunto, 2007), yang mana jenis data ini akan menggunakan beberapa siklus yang akan diterapkan dalam kelas untuk melihat hasil peningkatan dari penggunaan metode demonstrasi terhadap aktivitas belajar siswa dalam mata pelajaran ibadah shalat di kelas Kelas VII A yang berjumlah 25 orang pada MTSN I Lampung Timur yang berlokasi di Kecamatan Batanghari 38B Banjarrejo Lampung Timur. Dalam penelitian ini, peneliti menggunakan model desain siklus yang dikembangkan oleh Suharsimi Arikunto (Aqib, 2009), dan pelaksanaan tindakan ini dilaksanakan secara kolaboratif antara peneliti dengan guru mata pelajaran 
pendidikan agama Islam dengan menggunakan 2 (dua) siklus, yang mana masing-masing siklus mempunyai 3 (tiga) kali pertemuan.
Berikut merupakan konsep dasar dari siklus tindakan kelas yang akan peneliti laksanakan, yakni sebagai berikut:

\section{Gambar 1}

\section{Siklus Penelitian Tindakan Kelas}

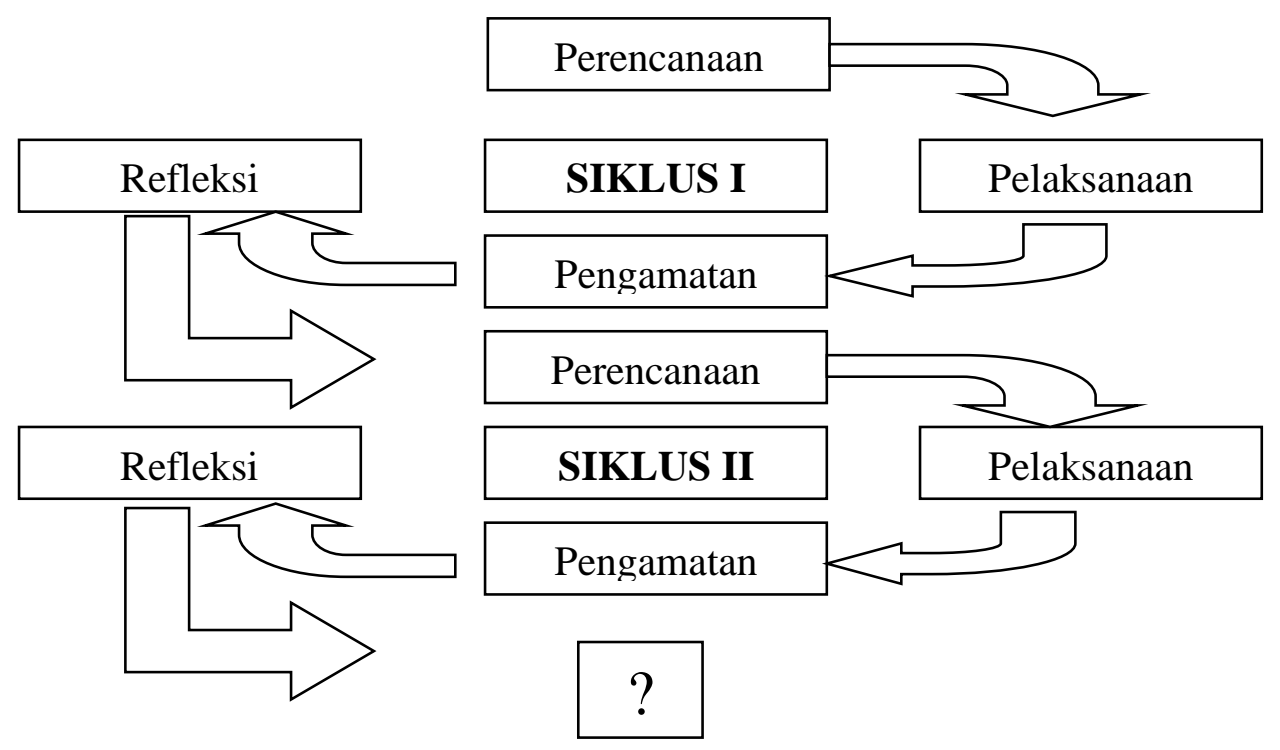

Untuk teknik pengumpul data, peneliti menggunakan observasi, tes hasil belajar dan dokumentasi. Dan untuk analisis data peneliti menggunakan analisis kualitatif (Fatoni, 2006). Data yang berhasil dikumpulkan ada yang bersifat kualitatif dan ada kuantitatif. data kualitatif diperoleh dari observasi sedangkan data kuantitatif diperoleh melalui tes hasil belajar, untuk proses pengitungan data kuantitatif menggunakan rumus statistk secara sederhana untuk beberapa sebagai berikut :

\section{Penilaian tugas dan tes}

Peneliti menjumlahkan nilai yang diperoleh siswa selanjutnya dibagi dengan jumlah siswa kelas tersebut sehingga diperoleh nilai rata-rata, untuk menghitung nilai rata-rata menggunakan rumus :

$$
\bar{X}=\frac{\sum X}{\sum n}
$$

Keterangan :

$\bar{X}=$ Nilai rata-rata

$\Sigma \mathrm{X}=$ Jumlah semua nilai hasil

$\Sigma \mathrm{n}=$ Jumlah siswa.

\section{Penilaian untuk aktivitas belajar}

Untuk melihat aktivitas siswa selama proses pembelajaran maka 
dilakukan pengamatan-pengamatan yang dicatat dalam lembar observasi aktivitas belajar. Untuk menghitung jumlah siswa yang beraktivitas menggunakan rumus sebagai berikut:

$$
P=\frac{\sum X}{n} \times 100 \%
$$

Keterangan :

$P=$ Persentase

$\Sigma \mathrm{X}=$ Jumlah siswa yang aktif

$\mathrm{N}=$ Jumlah siswa.

Adapun indikator keberhasilan yang diharapkan dalam penelitian tindakan kelas ini adalah sebagai berikut :

1. Rata-rata aktivitas belajar siswa meningkat disetiap siklus

2. Hasil belajar siswa yang memenuhi kriteria ketuntasan minimal $(\mathrm{KKM})$ dengan nilai $\geq 75$ mencapai $70 \%$ pada akhir siklus.

Tabel 4

Kriteria tingkat keberhasilan belajar siswa dalam persentase

\begin{tabular}{|c|l|l|}
\hline $\begin{array}{c}\text { Tingkat } \\
\text { Keberhasil } \\
\text { an \% }\end{array}$ & \multicolumn{1}{|c|}{ Kriteria } & Keterangan \\
\hline$>80 \%$ & Sangat tinggi & Tuntas \\
$60-79$ & Tinggi & Tuntas \\
$40-59$ & Sedang & Tuntas \\
$20-39$ & Rendah & Tidak Tuntas \\
$<20 \%$ & Sangat rendah. & Tidak Tuntas \\
\hline
\end{tabular}

\section{PEMBAHASAN}

Penelitian ini menggunakan penelitian tindakan kelas (PTK). Tujuan dari penelitian ini adalah untuk meningkatkan aktivitas dan hasil belajar ibadah shalat siswa Kelas VII A MTs N I Lampung Timur. Penelitian ini dilaksanakan dalam 2 siklus dan setiap siklus masing-masing 3 kali pertemuan, setiap pertemuan terdiri dari 2 jam pelajaran (2 x 40 menit). Metode demonstrasi merupakan jenis pembelajaran yang dirancang untuk meningkatkan aktivitas dan hasil belajar siswa dalam proses belajar. Data aktivitas siswa diamati dengan lembar observasi pada saat proses belajar mengajar berlangsung, dan data hasil belajar diperoleh dari hasil tes yang akan dilakukan pada setiap akhir siklus.

\section{a. SIKLUS I}

\section{1) Perencanaan}

Pada tahap ini peneliti merencanakan penerapan metode demonstrasi dalam proses pembelajaran dan setiap siklus terdiri dari 3 kali pertemuan. Hal-hal yang dilakukan dalam perencanaan adalah:

b. Menetapkan kelas penelitian, adapun kelas yang dijadikan sebagai objek penelitian adalah siswa Kelas VII A dengan jumlah 25 orang.

c. Menentukan pokok bahasan

\section{HASIL DAN PEMBAHASAN}


Materi pelajaran yang akan dibahas dalam penelitian ini adalah ibadah shalat.

d. Mempersiapkan sumber belajar seperti buku pelajaran

e. Membuat rencana pelaksanaan pembelajaran (RPP) dengan menggunakan metode demonstrasi

f. Membuat alat pengumpul data yaitu lembar observasi aktivitas siswa.

g. Membuat perangkat evaluasi (terlampir)

\section{2) Pelaksanaan Tindakan}

Pembelajaran pada siklus I dilaksanakan sebanyak 3 kali pertemuan yaitu :

a. Pertemuan 1 (Pertama)

Pertemuan ini dilaksanakan pada hari Senin, 04 Agustus 2020 dilakukan selama 2 jam pelajaran ( 2 x 40 menit). Materi menyebutkan shalat fardhu dengan indikatornya menyebutkan nama-nama shalat fardhu dan menunjukkan waktu pelaksanaannya. Dalam pertemuan pertama yaitu guru melakukan kegiatan pendahuluan yang meliputi apersepsi, motivasi dan menyampaikan tujuan yang ingin dicapai.

Pada kegiatan inti guru membagi siswa menjadi kelompok-kelompok secara heterogen yang terdiri dari 5 orang dan setiap siswa dari masing-masing kelompok memiliki nomor yang berbeda. Kemudian dilanjutkan dengan guru menjelaskan nama-nama shalat sunah dan menunjukkan waktu pelaksanaannya. Kemudian guru memberikan waktu kepada siswa untuk menunjukkan waktu pelaksanaan shalat fardhu dan nama-nama shalat fardhu. Setiap kelompok diminta untuk mempraktikkan ibadah shalat di depan kelas dan setiap siswa dari kelompok tersebut mengerjakan soal, siswa yang kurang paham dapat bertanya pada teman sekelompoknya lalu temannya membantu. Akhir dari pertemuan adalah menyampaikan kesimpulan bersama-sama siswa dan guru menginformasikan untuk materi pertemuan berikutnya.

\section{b. Pertemuan II (Kedua)}

Pertemuan ini dilaksanakan pada hari Kamis 14 Agustus 2020 dengan materi shalat fardhu dengan indikatornya menghafal bacaan shalat. Dalam pertemuan ini diawali dengan salam dan menyampaikan tujuan pelajaran sesuai dengan indikator pembelajaran dan menanyakan materi yang lalu (apersepsi).

Pada kegiatan inti guru membagi siswa menjadi kelompok-kelompok secara heterogen yang terdiri dari 5 orang dan setiap siswa dari masing-masing kelompok memiliki nomor yang berbeda. Kemudian dilanjutkan dengan guru menjelaskan materi bacaan shalat. Setiap kelompok diminta untuk menghafal bacaan shalat di depan kelas dan setiap siswa dari kelompok tersebut mengerjakan soal, siswa yang kurang paham dapat 
bertanya pada teman sekelompoknya lalu temannya membantu. Akhir dari pertemuan adalah menyampaikan kesimpulan bersama-sama siswa dan guru menginformasikan untuk materi pertemuan berikutnya.

\section{c. Pertemuan III}

Pertemuan ketiga dilaksanakan pada hari Senin, 18 Agustus 2020 dengan materi menyebutkan shalat fardhu dengan indikator menampilkan keserasian gerakan dan bacaan shalat. Dalam pertemuan ketiga ini diawali dengan salam dan menanyakan materi yang lalu, dan seperti biasa prosedur penelitian masih sama seperti pertemuan pertama dan kedua dan guru memberi tahu pertemuan berikutnya akan diadakan tes siklus I.

\section{3) Pengamatan/Observasi}

a. Hasil Observasi Aktivitas Siswa Siklus 1

Aktivitas siswa dalam pembelajaran pada siklus I diamati dengan lembar observasi yang telah dipersiapkan oleh peneliti. Data aktivitas belajar dapat dilhat pada tabel dibawah ini:

\section{Tabel 5}

Prosentase Aktivitas Belajar Siklus I

\begin{tabular}{|c|l|c|c|c|c|c|}
\hline \multirow{2}{*}{ No } & \multicolumn{1}{|c|}{ Indikator } & \multicolumn{3}{|c|}{ Pertemuan } & \multirow{2}{*}{ Rata-rata } & Ket \\
\cline { 2 - 6 } & & 1 & 2 & 3 & & Memperhatikan penjelasan \\
guru & $60 \%$ & $68 \%$ & $72 \%$ & $66.66 \%$ & $\mathrm{~T}$ \\
\hline 2 & Menghafal bacaan shalat & $56 \%$ & $60 \%$ & $68 \%$ & $61.33 \%$ & $\mathrm{TT}$ \\
\hline 3 & Melaksanakan ibadah shalat & $32 \%$ & $52 \%$ & $52 \%$ & $45 \%$ & $\mathrm{TT}$ \\
\hline 4 & $\begin{array}{l}\text { Gerakan shalat dengan baik } \\
\text { dan benar }\end{array}$ & $28 \%$ & $52 \%$ & $60 \%$ & $46,66 \%$ & $\mathrm{TT}$ \\
\hline 5 & $\begin{array}{l}\text { Membaca bacaan shalat } \\
\text { dengan benar }\end{array}$ & $32 \%$ & $40 \%$ & $48 \%$ & $40 \%$ & $\mathrm{TT}$ \\
\hline Rata-rata & $41.6 \%$ & $54.4 \%$ & $60 \%$ & $51,93 \%$ & $\mathrm{TT}$ \\
\hline
\end{tabular}

Keterangan : $\mathrm{T}$ : Tuntas

TT : Tidak Tuntas

Dari kelima aktivitas tersebut memperhatikan penjelasan guru melebihi target yang diinginkan berarti dinyatakan tuntas sedangkan menghafal bacaan shalat, gerakan dan bacaan siswa dalam melaksanakan ibadah shalat, masih dibawah target yang diinginkan berarti ketiga aktivitas tersebut dinyatakan tidak tuntas.

b. Hasil Belajar

Penilaian hasil belajar siswa didasarkan pada kemampuan akademik siswa yang diatas KKM yang dapat dilihat pada tabel berikut ini: 
Tabel 6

Persentase Komponen Analisis

\begin{tabular}{|c|l|c|}
\hline No & \multicolumn{1}{|c|}{ Komponen Analisis } & Siklus I \\
\hline 1 & Tuntas Belajar & $52 \%$ \\
\hline 2 & Tidak Tuntas Belajar & $48 \%$ \\
\hline
\end{tabular}

Tabel 7

Hasil belajar siswa siklus I

\begin{tabular}{|c|c|c|c|}
\hline No & Nama & Skor Total & $\begin{array}{c}\text { Kriteria } \\
\text { Ketuntasan }\end{array}$ \\
\hline 1 & Ajeng Puri Icarani & 70 & $\mathrm{~T}$ \\
\hline 2 & Anggara Saputra & 75 & $\mathrm{~T}$ \\
\hline 3 & Arneta Puri Maulidya & 70 & $\mathrm{~T}$ \\
\hline 4 & Aulia Rahma & 80 & $\mathrm{~T}$ \\
\hline 5 & Ayu Annisa Putri & 60 & TT \\
\hline 6 & Ayu Sekarkinasih & 45 & TT \\
\hline 7 & Billy Muliawan & 80 & $\mathrm{~T}$ \\
\hline 8 & Bisma Yudha Dikrama & 60 & TT \\
\hline 9 & Choirul Mustofa & 60 & TT \\
\hline 10 & Cynthia Serly Putri A. & 55 & TT \\
\hline 11 & Desi Indi Setiawan & 60 & TT \\
\hline 12 & Elfa Dita Mariska & 60 & TT \\
\hline 13 & Galang Bagus Wibisono & 70 & $\mathrm{~T}$ \\
\hline 14 & Hilwa Afita Sardeyana & 50 & TT \\
\hline 15 & Ichza Auliya Gumilar & 75 & $\mathrm{~T}$ \\
\hline 16 & Indra Yunandar & 60 & TT \\
\hline 17 & Kiwit Novitasari & 80 & $\mathrm{~T}$ \\
\hline 18 & Muhammad Abdul Jabar & 70 & $\mathrm{~T}$ \\
\hline 19 & Rahmadani Alfuazi & 40 & TT \\
\hline 20 & Resti Rahmawati & 60 & TT \\
\hline 21 & Risma Indah Deparista & 80 & $\mathrm{~T}$ \\
\hline 22 & Sandi Prabowo & 50 & TT \\
\hline 23 & Setiawan Margo Waluyo & 70 & $\mathrm{~T}$ \\
\hline 24 & Vina Desma Wati & 70 & $\mathrm{~T}$ \\
\hline 25 & Viola Zadestiara & 70 & $\mathrm{~T}$ \\
\hline
\end{tabular}

Sumber : MTs N I Lampung timur TP. 2019/2021

Keterangan :

Presentase Ketuntasan belajar

Tuntas : :52\%

Tidak Tuntas : $48 \%$ 
Berdasarkan tabel di atas bahwa siswa yang memperoleh nilai $>70$ yang tuntas belajar sebanyak $52 \%$. Sedangkan siswa yang memperoleh nilai $\geq 70$ yang tidak tuntas sebanyak $48 \%$.

\section{4) Refleksi Siklus I}

Dari hasil pengamatan oleh observer pada kegiatan siklus pertama ditemukan hal-hal sebagai berikut:

1. Beberapa siswa masih ada yang pasif pada saat bekerjasama bersama kelompoknya dan guru kurang memotivasi siswa tentang pentingnya dalam kelompok.

2. Siswa mengalami kesulitan dalam mempraktikkan ibadah shalat dan bacaannya.

3. Aktivitas siswa pada saat mempraktikkan ibadah shalat keseluruh kelas, siswa merasa takut, malu apabila salah dan kurang percaya diri.

Berdasarkan refleksi siklus I tindakan yang akan dilakukan pada siklus II yaitu:

1. Guru sebaiknya mengarahkan siswa untuk selalu bekerjasama dalam kelompoknya nada saat pembelajaran berlangsung dan guru mendekati kelompok yang pasif pada saat mempraktikkan ibadah shalat.

2. Guru hendaknya membimbing kelompok untuk mempraktikkan ibadah shalat serta memberikan arahan tentang gerakan dan bacaan ibadah shalat.

3. Memberikan penghargaan, memotivasi kepada siswa untuk maju ke depan untuk mempraktikkan ibadah shalat dan untuk lebih percaya diri dan tidak usah takut salah.

\section{b. Siklus II}

\section{1) Perencanaan}

Perencanaan tindakan yang akan dilakukan pada siklus II ini didasarkan hasil refleksi pada siklus I. Pada siklus ini guru lebih menekankan penjelasan materi dan merangsang siswa untuk ikut aktif dalam pembelajaran, memantau kesulitan siswa dan memotivasi siswa untuk semangat dalam mempraktikkan ibadah shalat atau bekerja sama.

\section{2) Pelaksanaan Tindakan}

Pembelajaran pada siklus II dilaksanakan sebanyak 3 kali pertemuan.

\section{a. Pertemuan I}

Pertemuan pertama dilaksanakan pada hari Senin, 1 September 2020 dilakukan selama 2 jam pelajaran $(2 \mathrm{x}$ 40 menit) dengan materi melaksanakan ibadah shalat dengan indikator melaksanakan shalat fardhu dzuhur dan ashar. Dalam pertemuan pertama yaitu guru melakukan kegiatan pendahuluan yang meliputi apersepsi, motivasi dan menyampaikan tujuan yang ingin dicapai. 
Pada kegiatan inti guru membagi siswa menjadi kelompok-kelompok secara heterogen yang terdiri dari 5 orang dan setiap siswa dari masing-masing kelompok memiliki nomor yang berbeda. Kemudian dilanjutkan dengan guru menjelaskan cara pelaksanaan shalat dzuhur dan ashar. Kemudian guru memberikan waktu kepada siswa untuk melaksanakan shalat dzuhur. Setiap kelompok diminta untuk mempraktikkan cara pelaksanaannya di depan kelas dan setiap siswa dari kelompok tersebut mengerjakan soal, siswa yang kurang paham dapat bertanya pada teman sekelompoknya lalu temannya membantu. Akhir dari pertemuan adalah menyampaikan kesimpulan bersama-sama siswa dan guru menginformasikan untuk materi pertemuan berikutnya.

\section{b. Pertemuan II}

Pertemuan kedua dilaksanakan pada hari Kamis, 04 September 2020 dengan materi melaksanakan bahasan ibadah shalat, dengan indikator melaksanakan shalat magrib, isya, dan subuh. Dalam pertemuan ini diawali dengan salam dan menyampaikan tujuan pelajaran sesuai dengan indikator pembelajaran dan menanyakan materi yang lalu (apersepsi).

Pada kegiatan inti guru membagi siswa menjadi kelompok-kelompok secara heterogen yang terdiri dari 5 orang dan setiap siswa dari masing-masing kelompok memiliki nomor yang berbeda. Kemudian dilanjutkan dengan guru menjelaskan cara pelaksanaan shalat magrib, isya, dan subuh, kemudian guru memberikan waktu kepada siswa untuk melaksanakan shalat magrib, isya, dan subuh. Setiap kelompok diminta untuk mempraktikkan pelaksanaan shalat fardhu di depan kelas dan setiap siswa dari kelompok tersebut mengerjakan soal, siswa yang kurang paham dapat bertanya pada teman sekelompoknya lalu temannya membantu. Akhir dari pertemuan adalah menyampaikan kesimpulan bersama-sama siswa dan guru menginformasikan untuk materi pertemuan berikutnya

\section{c. Pertemuan III}

Pertemuan pertama dilaksanakan pada hari Senin, 08 September 2020 dengan materi melaksanakan shalat fardhu dengan indikator mengamalkan shalat fardhu dengan baik dan benar. Dalam pertemuan ketiga ini diawali dengan salam dan menanyakan materi yang lalu, dan seperti biasa prosedur penelitian masih sama seperti pertemuan pertama dan kedua dan guru memberi tahu pertemuan berikutnya akan diadakan tes siklus II.

\section{3). Pengamatan / observasi}

a. Hasil Observasi Aktivitas Siswa Siklus II

Data hasil Aktivitas belajar dalam pembelajaran pada siklus II dapat dilhat pada tabel dibawah ini: 
Tabel 7

Prosentase Aktivitas Belajar Siswa Pada Siklus II

\begin{tabular}{|c|c|c|c|c|c|c|}
\hline \multirow{2}{*}{ No } & \multirow{2}{*}{ Indikator } & \multicolumn{3}{|c|}{ Pertemuan } & \multirow{2}{*}{ Rata-rata } & \multirow{2}{*}{ Ket } \\
\hline & & 1 & 2 & 3 & & \\
\hline 1 & $\begin{array}{l}\text { Memperhatikan penjelasan } \\
\text { guru }\end{array}$ & $72 \%$ & $72 \%$ & $74 \%$ & $72.66 \%$ & $\mathrm{~T}$ \\
\hline 2 & Menghafal bacaan shalat & $64 \%$ & $68 \%$ & $72 \%$ & $68 \%$ & $\mathrm{~T}$ \\
\hline 3 & Melaksanakan ibadah shalat & $64 \%$ & $68 \%$ & $76 \%$ & $69.33 \%$ & $\mathrm{~T}$ \\
\hline 4 & $\begin{array}{l}\text { Gerakan salat dengan baik } \\
\text { dan benar }\end{array}$ & $60 \%$ & $64 \%$ & $76 \%$ & $66.66 \%$ & $\mathrm{~T}$ \\
\hline 5 & $\begin{array}{l}\text { Membaca bacaan shalat } \\
\text { dengan benar }\end{array}$ & $64 \%$ & $68 \%$ & $72 \%$ & $68 \%$ & $\mathrm{~T}$ \\
\hline & Rata-rata & $64.8 \%$ & $68 \%$ & $74 \%$ & $68.93 \%$ & $\mathrm{~T}$ \\
\hline
\end{tabular}

Keterangan : $\mathrm{T}$ : Tuntas

TT : Tidak Tuntas

b. Hasil Belajar

Data hasil belajar pada proses pembelajaran siklus II dapat dilihat pada tabel di bawah ini:

Tabel 8

Hasil belajar siswa siklus II

\begin{tabular}{|c|c|c|c|}
\hline No & Nama & $\begin{array}{c}\text { Skor } \\
\text { Total }\end{array}$ & $\begin{array}{c}\text { Kriteria } \\
\text { Ketuntasan }\end{array}$ \\
\hline 1 & Ajeng Puri Icarani & 70 & $\mathrm{~T}$ \\
\hline 2 & Anggara Saputra & 80 & $\mathrm{~T}$ \\
\hline 3 & Arneta Puri Maulidya & 90 & $\mathrm{~T}$ \\
\hline 4 & Aulia Rahma & 90 & $\mathrm{~T}$ \\
\hline 5 & Ayu Annisa Putri & 95 & $\mathrm{~T}$ \\
\hline 6 & Ayu Sekarkinasih & 70 & $\mathrm{~T}$ \\
\hline 7 & Billy Muliawan & 60 & $\mathrm{TT}$ \\
\hline 8 & Bisma Yudha Dikrama & 75 & $\mathrm{~T}$ \\
\hline 9 & Choirul Mustofa & 80 & $\mathrm{~T}$ \\
\hline 10 & Cynthia Serly Putri A. & 90 & $\mathrm{~T}$ \\
\hline 11 & Desi Indi Setiawan & 60 & $\mathrm{TT}$ \\
\hline 12 & Elfa Dita Mariska & 70 & $\mathrm{~T}$ \\
\hline 13 & Galang Bagus Wibisono & 60 & $\mathrm{~T}$ \\
\hline 14 & Hilwa Afita Sardeyana & 60 & $\mathrm{~T}$ \\
\hline 15 & Ichza Auliya Gumilar & 70 & $\mathrm{TT}$ \\
\hline 16 & Indra Yunandar & 50 & $\mathrm{~T}$ \\
\hline 17 & Kiwit Novitasari & 90 & $\mathrm{~T}$ \\
\hline 18 & Muhammad Abdul Jabar & 70 & \\
\hline
\end{tabular}




\begin{tabular}{|c|c|c|c|}
\hline No & Nama & $\begin{array}{c}\text { Skor } \\
\text { Total }\end{array}$ & $\begin{array}{c}\text { Kriteria } \\
\text { Ketuntasan }\end{array}$ \\
\hline 19 & Rahmadani Alfuazi & 70 & $\mathrm{~T}$ \\
\hline 20 & Resti Rahmawati & 70 & $\mathrm{~T}$ \\
\hline 21 & Risma Indah Deparista & 80 & $\mathrm{~T}$ \\
\hline 22 & Sandi Prabowo & 60 & $\mathrm{TT}$ \\
\hline 23 & Setiawan Margo Waluyo & 60 & $\mathrm{~T}$ \\
\hline 24 & Vina Desma Wati & 85 & $\mathrm{~T}$ \\
\hline 25 & Viola Zadestiara & 90 & $\mathrm{~T}$ \\
\hline
\end{tabular}

Sumber : MTs Negeri 1 Lampung timur TP. 2019/2020

Presentase Ketuntasan belajar

Tuntas : $80 \%$

Tidak Tuntas : $20 \%$

\begin{tabular}{|c|c|c|}
\hline No & Komponen Analisis & Siklus I \\
\hline 1 & Tuntas Belajar & $72 \%$ \\
\hline 2 & Tidak Tuntas Belajar & $28 \%$ \\
\hline
\end{tabular}

Berdasarkan tabel di atas bahwa siswa yang memperoleh nilai $>70$ yang tuntas belajar sebanyak $72 \%$. Sedangkan siswa yang memperoleh nilai $\geq 70$ yang tidak tuntas sebanyak $28 \%$. Hal ini menunjukkan pada siklus II telah mencapai di atas target yaitu $70 \%$ siswa yang mendapat nilai $>70$.

\section{4). Refleksi Siklus II}

Dari hasil penelitian pada siklus II diketahui bahwa tindakan pembelajaran dengan menggunakan metode demonstrasi sudah cukup baik dibandingkan dengan siklus I maka dapat disimpulkan sebagai berikut: (1) Siswa menjadi paham tentang materi dan aktif dalam kegiatan pembelajaran, (2) Siswa bersemangat untuk bekerjasama dalam kelompok.

\section{HASIL PENELITIAN}

\section{Aktivitas Siswa Pada Saat Proses Pembelajaran}

Dari hasil penelitian diperoleh rasa-rata presentase aktivitas belajar siswa dalam metode demonstasi pada siklus I dan siklus II dapat dilihat pada tabel di bawah ini:

Tabel 9

Rata-rata Prosentase Aktivitas Siswa dalam Metode Demonstrasi pada Siklus I dan Siklus II.

\begin{tabular}{|c|c|c|c|c|}
\hline No & Indikator & Siklus I & Siklus II & Peningkatan \\
\hline 1 & Memperhatikan penjelasan guru & $66.66 \%$ & $72.66 \%$ & $6 \%$ \\
\hline
\end{tabular}




\begin{tabular}{|c|l|c|c|c|}
\hline 2 & Menghafal bacaan shalat & $61.33 \%$ & $68 \%$ & $6,67 \%$ \\
\hline 3 & Melaksanakan ibadah shalat & $45 \%$ & $69,3 \%$ & $24.3 \%$ \\
\hline 4 & Gerakaan shalat dengan baik dan benar & $46,66 \%$ & $66.66 \%$ & $20 \%$ \\
\hline 5 & Membaca bacaan shalat dengan benar & $40 \%$ & 68 & $28 \%$ \\
\hline & Rata-rata & $51.93 \%$ & $68.92 \%$ & $16.99 \%$ \\
\hline
\end{tabular}

\section{Gambar 2 Peningkatan Aktivitas Siswa Setiap Siklus}

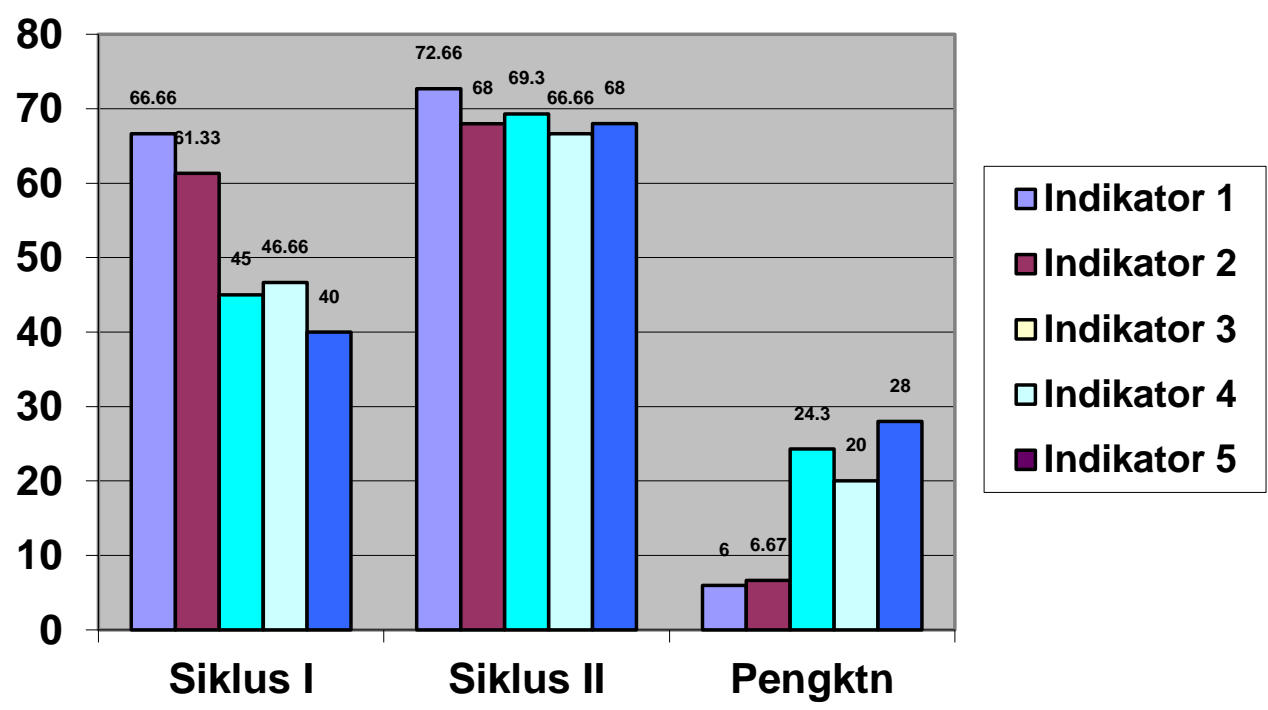

Pembahasan aktivitas siswa pada saat pembelajaran pada siklus I dan siklus II tiap-tiap indikator sebagai berikut:

a. Memperhatikan penjelasan guru

Aktivitas siswa saat guru menerangkan yang aktif memperhatikan guru pada siklus I sebesar $66.66 \%$. Siswa yang lain belum termotivasi untuk belajar dan tidak memperhatikan pelajaran. Untuk meningkatkan aktivitas tersebut guru memberikan perhatian dan menegur siswa yang tidak memperhatikan pelajaran. Untuk meningkatkan aktifitas tersebut guru memberikan perhatian dan menegur siswa, yang tidak memperhatikan pelajaran. Pada siklus II, aktivitas memperhatikan saat guru menjelaskan sebesar $72.66 \%$ dan mengalami peningkatan sebesar $6 \%$.

b. Menghafal bacaan shalat

Pada. siklus I, aktivitas siswa Menghafal bacaan shalat sebesar $61,33 \%$. Pada siklus I siswa masih malas dan menganggap remeh pelajaran. Untuk meningkatkan aktivitas tersebut guru memberikan pengarahan. Kepada siswa untuk bersemangat mencatat, untuk mengingatkan siswa jika lupa materi yang dipelajari. Pada siklus II aktivitas 
mendemonstrasi ibadah shalat sebesar $68 \%$ dan mengalami peningkatan sebesar $6.67 \%$.

c. Melaksanakan ibadah shalat

Pada siklus 1, aktivitas melaksanakan ibadah shalat sebesar 45\%. Pada siklus I masih banyak siswa yang pasif dan kurang termotivasi, untuk melaksanakan ibadah shalat Untuk meningkatkan aktivitas tersebut guru memberikan pengarahan kepada siswa dan guru memberikan perhatian yang lebih kepada siswa yang pasif. Pada siklus II, aktivitas siswa aktif dalam melaksanakan ibadah shalat sebesar $69.3 \%$ dan mengalami peningkatan sebesar $24.3 \%$

d. Gerakan shalat dengan baik dan benar

Pada siklus I Gerakan shalat dengan baik dan benar sebesar 46,66\%. Pada siklus I masih banyak siswa yang mengalami kesulitan dalam menjalankan kerjasama dalam kelompok. Untuk meningkatkan aktivitas tersebut guru memberikan penekanan penjelasan materi dan merangsang siswa untuk melakukangerakan shalat dengan baik dan benar. Akhirnya pada siklus II aktivitas siswa untuk melakukan Gerakan shalat dengan baik dan benar sebesar $66,66 \%$ dan mengalami peningkatan sebesar $20 \%$.

e. Membaca bacaan shalat dengan benar

Pada siklus I aktivitas siswa Membaca bacaan shalat dengan benar sebesar 40\%. Pada siklus I masih banyak siswa tidak bisa membaca bacaan shalat dengan benar. Untuk meningkatkan aktivitas tersebut guru memberi pemahaman, motivasi, menerangkan kepada siswa untukmenghafal bacaan shalat dengan benar. Pada siklus II aktivitas siswa dalam membaca bacaan shalat dengan baik dan benar sebesar $68 \%$ dan mengalami peningkatan sebesar $28 \%$.

\section{Hasil Belajar}

Dari hasil penelitian diperoleh data skor hasil belajar matematika siswa dalam metode demonstrasi pada siklus I dan siklus II dapat dilihat pada tabel berikut ini:

Tabel 10

Hasil belajar siswa Siklus I dan siklus II

\begin{tabular}{|l|l|c|c|c|}
\hline No & \multicolumn{1}{|c|}{ Nama } & Siklus I & Siklus II & Peningkatan \\
\hline 1 & Ajeng Puri Icarani & 70 & 70 & 0 \\
\hline 2 & Anggara Saputra & 75 & 80 & +5 \\
\hline 3 & Arneta Puri Maulidya & 70 & 90 & +20 \\
\hline 4 & Aulia Rahma & 80 & 90 & +10 \\
\hline 5 & Ayu Annisa Putri & 60 & 95 & +35 \\
\hline
\end{tabular}




\begin{tabular}{|l|l|c|c|c|}
\hline 6 & Ayu Sekarkinasih & 45 & 70 & +20 \\
\hline 7 & Billy Muliawan & 80 & 60 & +20 \\
\hline 8 & Bisma Yudha Dikrama & 60 & 75 & +15 \\
\hline 9 & Choirul Mustofa & 60 & 80 & +20 \\
\hline 10 & Cynthia Serly Putri A. & 55 & 90 & +35 \\
\hline 11 & Desi Indi Setiawan & 60 & 60 & 0 \\
\hline 12 & Elfa Dita Mariska & 60 & 70 & +10 \\
\hline 13 & Galang Bagus Wibisono & 70 & 60 & -10 \\
\hline 14 & Hilwa Afita Sardeyana & 50 & 60 & +10 \\
\hline 15 & Ichza Auliya Gumilar & 75 & 70 & -5 \\
\hline 16 & Indra Yunandar & 60 & 50 & -10 \\
\hline 17 & Kiwit Novitasari & 80 & 90 & +10 \\
\hline 18 & Muhammad Abdul Jabar & 70 & 70 & 0 \\
\hline 19 & Rahmadani Alfuazi & 40 & 70 & +30 \\
\hline 20 & Resti Rahmawati & 60 & 70 & +10 \\
\hline 21 & Risma Indah Deparista & 80 & 80 & 0 \\
\hline 22 & Sandi Prabowo & 50 & 60 & +10 \\
\hline 23 & Setiawan Margo Waluyo & 70 & 60 & -10 \\
\hline 24 & Vina Desma Wati & 70 & 85 & +15 \\
\hline 25 & Viola Zadestiara & 70 & 90 & +20 \\
\hline
\end{tabular}

Sumber : MTs N I Lampung timur TP. 2019/2020

\begin{tabular}{|c|l|c|c|c|}
\hline No & Komponen Analisis & Siklus I & Siklus II & Keterangan \\
\hline 1 & Tuntas Belajar & $52 \%$ & $72 \%$ & $20 \%$ (meningkat) \\
\hline 2 & Tidak Tuntas Belajar & $48 \%$ & $28 \%$ & $20 \%$ (menurun) \\
\hline
\end{tabular}

Dari tabel di atas diketahui bahwa hasil belajar siswa yang tuntas pada siklus I yaitu $52 \%$ dan yang tidak tuntas, sebesar $48 \%$.

Pada siklus I tidak tuntas karena masih dibawah target keberhasilan yaitu $70 \%$ dari $\mathrm{KKM} \geq 75$.

Kemudian peneliti melakukan tindakan siklus II. Pada siklus II hasil belajar siswa yang tuntas sebesar $72 \%$ dan yang tidak tuntas sebesar $28 \%$.
Dengan demikian pada siklus II hasil belajar meningkat sebesar $20 \%$.

Pada pembelajaran siklus II, sudah memenuhi target kriteria ketuntasan minimal (KKM) yaitu 70\% siswa yang memperoleh nilai $\geq 75$.

Peningkatan ini disebabkan karena proses pembelajaran pada siklus II dilakukan upaya-upaya memperbaiki pencapaian target indikator aktivitas dan hasil belajar yang belum tercapai pada siklus I. Upaya-upaya yang 
dilakukan antara lain: mengarahkan siswa untuk selalu bekerjasama, lebih menekankan penjelasan materi, memberikan penghargaan, memotivasi siswa dan menimbulkan rasa percaya diri kepada siswa. Karena pada siklus II hasil belajar siswa yang dikatakan tuntas belajar mencapai $70 \%$ dan sudah mencapai kriteria keberhasilan jadi dalam penelitian ini, peneliti tidak merencanakan tindakan selanjutnya

\section{KESIMPULAN}

Berdasarkan hasil penelitian tindakan kelas yang telah dilakukan, maka dapat diambil kesimpulan pembelajaran dengan menggunakan metode demonstrasi yakni penggunaan metode demonstrasi dapat meningkatkan aktivitas belajar dalam ibadah shalat yang mana rata-rata aktivitas belajar siswa ibadah shalat secara keseluruhan mengalami peningkatan sekitar $70 \%$ dari siswa yang memperoleh nilai $\geq 75$.

\section{A. DAFTAR PUSTAKA}

Aqib, Z. (2009). dkk, Penelitian Tindakan Kelas, Cet. II; Bandung: CV. Yrama Widya.

Arief, A. (2002). Pengantar ilmu dan metodologi pendidikan islam. Ciputat Pers.

Arikunto, S. (2007). Suhardjono; Supardi. 2006. Penelitian Tindakan Kelas.

Daradjat, Z. (2016). Metodik khusus pengajaran agama Islam.

Departemen Agama, R. I. (2005). alQuran dan Terjemahnya. Bandung: Diponegoro.

Fatoni, A. (2006). Metodologi Penelitian dan teknik penyusunan Skripsi. Jakarta: PT Rineka Cipta.

Ferista, K. M. (2011). Pengaruh pendidikan agama Islam terhadap kedisplinan beribadah sholat siswa: studi kasus di SMP Muhammadiyah 24 Sambeng Lamongan. UIN Sunan Ampel Surabaya.

Hamalik, O. (2004). Proses belajar mengajar. Bumi Aksara.

Slameto. (2003). Belajar dan Faktorfaktor yang Mempengaruhinya, cet. 3. Jakarta: Rineka Cipta.

Nashar, H. (2004). Peranan Motivasi dan Kemampuan awal dalam kegiatan Pembelajaran. Jakarta: Delia Press. 